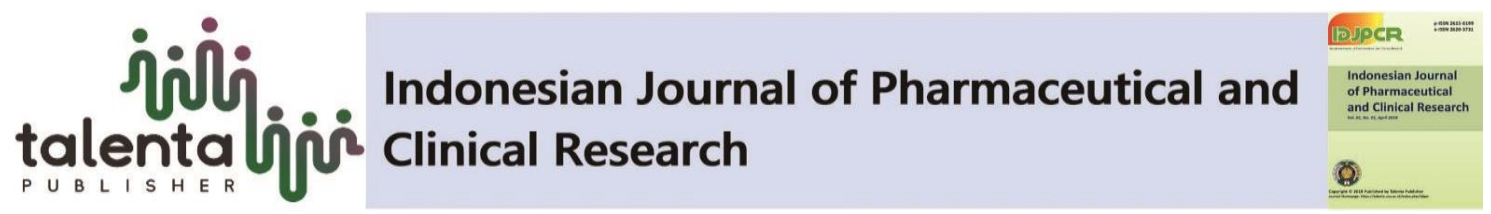

\title{
Evaluation of Waiting Time for Outpatient Prescription Services at the Pharmacy Installation at the Universitas Sumatera Utara Hospital
}

\author{
Muhammad Yunus $^{1 *}$, Wiryanto $^{2}$, Yuandani ${ }^{2}$ \\ ${ }^{1}$ Postgraduate Programs Faculty of Pharmacy, Universitas Sumatera Utara, Medan, 20155, Indonesia \\ ${ }^{2}$ Department of Pharmacology, Faculty of Pharmacy, Universitas Sumatera Utara, Medan, 20155 , \\ Indonesia
}

\begin{abstract}
The pharmacy installation is one of the units in the hospital that provides. service products and services in the form of prescription services. Prescription service asthe front line of pharmacy services to patients must be managed properly becausethe quality of pharmaceutical prescription service which is generally associated with the speed ingiving service. This research is a descriptive type of research with prospective data collection from March-June 2019 to evaluate the waiting time for outpatient prescription services at the Hospital Pharmacy Installation of the Universitas Sumatera Utara. The data taken were 357 outpatient prescriptions. The results of this study indicate the total average length of time waiting for outpatients for the provision of non-fake drugs at the Pharmacy Installation of Outpatients at the University of Sumatera Utara Hospital at 09.00 - 11.00 is 29.10 minutes, at $11.00-13.00$ is 34.44 . minutes and at 13.00 - finished 42.60 minutes. The average length of waiting time for outpatients for the provision of compound drugs at the Outpatient Pharmacy Installation of the University of Sumatera Utara Hospital at 09.00 - 11.00 is 51.67 minutes, 11.00 - 13.00 hours is 62.27 minutes and at 13.00 - completion was 65.71 minutes. The waiting time for prescription services is $\leq 60$ minutes.Based on the results of research conducted at the Outpatient Pharmacy Installation at the University of Sumatera Utara Hospital, non-concocted prescription drugs meet the requirements if the service time speed is $\leq 30$ minutes and the concocted drug prescription fulfills the requirements if the service time speed is $\leq 60$ minutes.
\end{abstract}

Keywords: Waiting time, prescription service, hospital pharmacy installation

\begin{abstract}
Abstrak. Instalasi farmasi adalah salah satu unit di rumah sakit yang memberikan layanan produk dan jasa dalam bentuk pelayanan resep. Pelayanan resep sebagai garis depan pelayanan farmasi kepada pasien harus dikelola dengan baik, karena mutu pelayanan resep farmasi yang umumnya dikaitkan dengan kecepatan dalam memberikan pelayanan. Penelitian ini merupakan jenis penelitian deskriptif dengan pengambilan data secara prospektif selama bulan maret-juni 2019 untuk mengevaluasi waktu tunggu pelayanan resep rawat jalan di Instalasi Farmasi Rumah Sakit Universitas Sumatera. Data yang diambil sebanyak 357 resep pasien rawat jalan. Hasil penelitian ini menunjukkan total lama rata-rata waktu tunggu pasien rawat jalan untuk penyediaan obat non rancikan di Instalasi Farmasi Pasien Rawat Jalan Rumah Sakit Universitas Sumatera Utara pada pukul 09.00 - 11.00 adalah 29,10 menit, pada pukul 11.00 - 13.00 adalah 34,44 menit dan pada pukul 13.00 - selesai 42,60 menit. Lama rata-rata waktu tunggu pasien rawat
\end{abstract}

*Corresponding author at: Postgraduate Programs Faculty of Pharmacy, Universitas Sumatera Utara, Medan, 20155, Indonesia

E-mail address: yunusmy11@yahoo.com 
jalan untuk penyediaan obat rancikan di Instalasi Farmasi Pasien Rawat Jalan Rumah Sakit Universitas Sumatera Utara pada pukul 09.00 - 11.00 adalah 51,67 menit, pada pukul 11.00 - 13.00 adalah 62,27 menit dan pada pukul 13.00 - selesai adalah 65,71 menit. Waktu tunggu pelayanan resep yaitu untuk resep racikan $\leq 60$ menit.Berdasarkan hasil penelitian yang dilaksanakan di Instalasi Farmasi Rawat Jalan Rumah Sakit Universitas Sumatera Utara, bahwa resep obat non racikan, memenuhi persyaratan apabila kecepatan waktu pelayanan $\leq 30$ menit dan resep obat racikan, memenuhi persyaratan apabila kecepatan waktu pelayanan $\leq 60$ menit.

Kata kunci : Waktu tunggu, pelayanan resep, instalasi farmasi rumah sakit

Received 12 December 2020 | Revised 8 January 2021 | Accepted 10 January 2021

\section{Introduction}

Health is a state of health, whether physically, mentally, spiritually, or socially, which enables everyone to live productively socially and economically. Therefore, every activity and effort to improve the level of public health as high as possible is carried out based on the principles of nondiscrimination, participation, and protection [1].

Hospital, which is one of the public health service facilities, has a very important role in improving the public health status. Hospital according to the Law of the Republic of Indonesia Number 44 of 2009 is a health service institution that provides complete individual health services that provide inpatient, outpatient, and emergency services [2].

Waiting time is one of the minimum standards for pharmacy serviceshospital, the waiting time for non-concocted drug services is a grace periodstarting from the patient submitting the prescription to receiving non-concocted drugswith a minimum standard set by the Ministry of Health, namely $\leq 30$ minutes, while the waiting time for concocted drug services is the starting timethe patient submits the prescription until he receives the concocted drug, which is $\leq 60$ minutes[3].

The minimum standard of pharmacy service in a hospital is timeWait. The waiting time for finished drug services is the starting periodpatients submit prescriptions to receive finished drugs, with the minimum standard set by the Ministry of Health is $\leq 30$ minutes, while the waiting time for concocted drug services is a grace periodstarting from the patient submitting the prescription to receiving the concocted drug, namely $\leq 60$ minutes [1]. The waiting time for prescription drug services is getting longerfast compared to the service time of prescription concoction drugs becauseprescription drug services do not go through a compounding process [4].

Based on the above background, until now there has been no researchabout the waiting time for outpatient prescription services at the Pharmacy Installation in Universitas Sumatera Utara. Research is neededto know the waiting time for outpatient prescription services at the Pharmacy Installation in UniversitasSumatera Utara Hospital. 


\section{Methods}

This research is a descriptive research type with prospective data collection to evaluate the waiting time for outpatient prescription services at the Pharmacy Installation at the University of Sumatera Utara Hospital. The data were obtained from prospective data collection which was carried out at the time the research was carried out by direct observation of the waiting time for prescription services in March-June 2019 at the Pharmacy Installation at the Hospital of Sumatera Utara. The number of samples as a source of research data was calculated based on binominal proportions [5] namely 356 people, and in this study were fulfilled to be 357 samples.

\section{Results and Discussion}

\subsection{Characteristics of the Recipe}

Sample in this study as many as 357 Prescription, consisting of 320 non-concocted Prescription and 37 Prescription., consisting of 320 non-concocted Prescription and 37 Prescription. The percentage of concocted and non-concocted Prescription can be seen in table 1 and figure 1 shows the number of samples based on the type of concoction and non-concoction Prescription served in the hospital pharmacy installation of the Universitas Sumatera Utara Hospital.

Table 1. The percentage of concocted and non-concocted Prescription

\begin{tabular}{clcc}
\hline No. & \multicolumn{1}{c}{ Type of recipe } & $\begin{array}{c}\text { Number of } \\
\text { samples }\end{array}$ & Percentage \\
\hline 1. & Non-Blend Prescription & 320 Prescription & $89,6 \%$ \\
2. & Recipe Mix & 37 Prescription & $10,4 \%$ \\
& Total & 357 Prescription & $100 \%$ \\
\hline
\end{tabular}

Prescription services, both finished and concocted drugs, are a form of clinical pharmacy service in hospitals. One of the indicators used to evaluate the quality of service is the length of time waiting for prescription services in pharmaceutical installations, as stated in the Regulation of the Minister of Health of the Republic of Indonesia No. 72 of 2016 [6] concerning Standards for Pharmaceutical Services in hospitals. The waiting time for prescription services is a grace period from the time the patient submits the prescription until the patient receives the drug [7] This indicator of the average speed of prescription service aims to illustrate the speed of pharmacy service so that it can produce quality dimensions in the form of effectiveness, continuity of service, and efficiency [1].

The number of samples used was 357 outpatient prescriptions, calculated based on the gameshow formula with a confidence level of $95 \%$. Data were collected prospectively for 2 months at the Hospital Pharmacy Unit of the University of Sumatera Utara. The results of the average waiting time for Prescription as a whole can be seen in Table 4.3. 
Based on table 4.3 it can be seen that the average waiting time for non-concocted Prescription (09.00 - 11.00) is 29.10 minutes and concocted Prescription (09.00 - 11.00) is 51.67 minutes. The average waiting time for non-concocted Prescription (11.00 - 13.00) is 34.44 minutes and concoction Prescription (11.00 - 13.00) is 62.27 minutes, while the average waiting time for nonconcocted Prescription (13.00 - Finish) is 42, 59 minutes and the concoction recipe (13.00 - End) is 65.27 minutes. So the waiting time for prescription services at the pharmacy installation at the University of Sumatera Utara Hospital at 11.00 - 13.00 and 13.00 - finished still does not meet the minimum hospital service standards according to the Minister of Health Decree No.129 of 2008 which has a minimum service standard for non-concocted prescriptions $\leq 30$ minutes and recipe concoctions $\leq 60$ minutes. The waiting time for concoction prescription services is longer than that of non-concocted prescription services because concoction prescriptions not only prepare drugs but also need to calculate the dose of drugs needed, as well as perform drug compounding. This is following previous research that there is a relationship between the type of recipe and the time of prescription service [8]. Prescription received at 11.00-13.00 and 13.00finished have a longer waiting time than Prescription received at 09.00-11.00 all poles are complete in providing services so that many Prescription pile up at 11.00 and above.

The Sumatera Utara University Hospital is a teaching hospital that has a pharmaceutical installation and serves outpatients consisting of BPJS, general, and emergency room patients as well as inpatients. Prescription services, both concocted and non-concocted prescriptions, are a form of clinical pharmacy service in hospitals. One of the indicators used to evaluate the quality of service is the length of time waiting for prescription services at pharmaceutical installations, as based on the Regulation of the Minister of Health of the Republic of Indonesia No.72 of 2016 concerning Standards for Pharmaceutical Services in hospitals. The waiting time for prescription services is a grace period from the time the patient submits the prescription until the patient receives the drug [6].

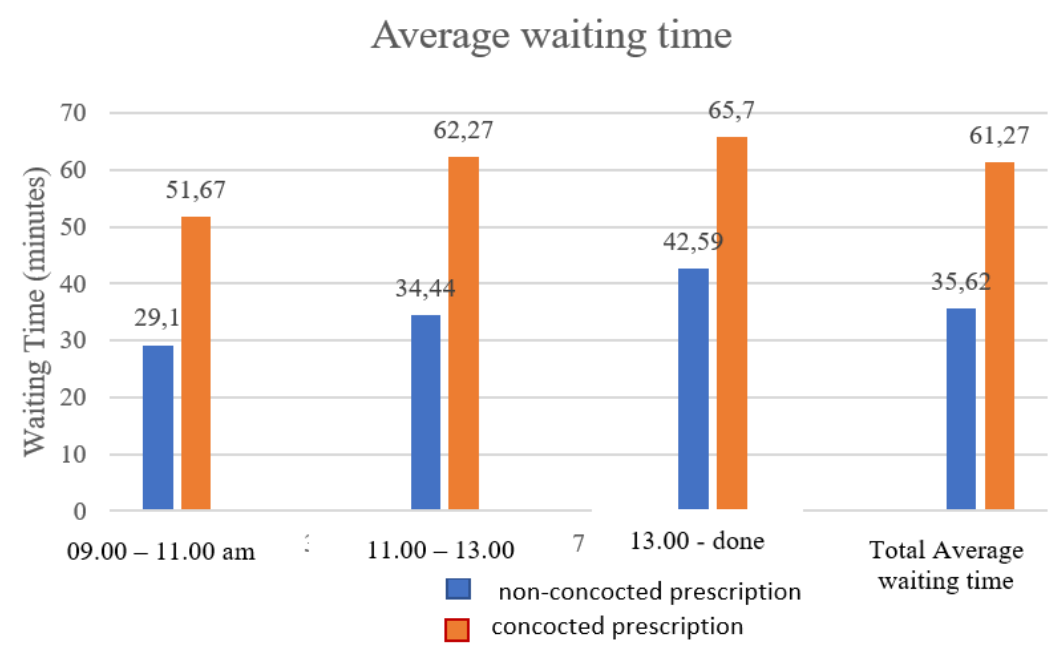

Figure 1. Waiting time data 
Table 2. Average waiting time for prescription services at the hospital outpatient pharmacy installation on weekdays

\begin{tabular}{|c|c|c|c|c|c|c|c|c|c|}
\hline \multirow{3}{*}{ Day } & \multirow{3}{*}{$\begin{array}{c}\text { Types of } \\
\text { Prescription }\end{array}$} & \multicolumn{8}{|c|}{ Recipe received at } \\
\hline & & \multicolumn{2}{|c|}{ 09.00-11.00 } & \multicolumn{2}{|c|}{ 11:00-13:00 } & \multicolumn{2}{|c|}{ 13:00-Off } & \multicolumn{2}{|c|}{ Total } \\
\hline & & $\begin{array}{c}\text { Total } \\
\text { Prescription }\end{array}$ & $\begin{array}{c}\text { Waiting } \\
\text { Time } \\
\text { (minutes) }\end{array}$ & $\begin{array}{c}\text { Total } \\
\text { Prescription }\end{array}$ & $\begin{array}{c}\text { Waiting } \\
\text { Time } \\
\text { (minutes) }\end{array}$ & $\begin{array}{c}\text { Total } \\
\text { Prescription }\end{array}$ & $\begin{array}{c}\text { Waiting } \\
\text { Time } \\
\text { (minutes) }\end{array}$ & $\begin{array}{c}\text { Total } \\
\text { Prescription }\end{array}$ & $\begin{array}{c}\text { Waiting } \\
\text { Time } \\
\text { (minutes) }\end{array}$ \\
\hline \multirow[t]{3}{*}{ Monday } & non- & & & & & & & & \\
\hline & $\begin{array}{l}\text { concocted } \\
\text { recipe }\end{array}$ & 20 & 640 & 21 & 756 & 23 & 1035 & 64 & 2431 \\
\hline & $\begin{array}{l}\text { concoction } \\
\text { recipe }\end{array}$ & 2 & 116 & 2 & 126 & 3 & 202 & 7 & 444 \\
\hline \multirow[t]{3}{*}{ Tuesday } & non- & & & & & & & & \\
\hline & $\begin{array}{l}\text { concocted } \\
\text { recipe }\end{array}$ & 20 & 560 & 21 & 735 & 23 & 966 & 64 & 2261 \\
\hline & $\begin{array}{l}\text { concoction } \\
\text { recipe }\end{array}$ & 1 & 45 & 2 & 135 & 4 & 260 & 7 & 440 \\
\hline \multirow[t]{3}{*}{ Wednesday } & non- & & & & & & & & \\
\hline & $\begin{array}{l}\text { concocted } \\
\text { recipe }\end{array}$ & 20 & 580 & 21 & 672 & 23 & 1012 & 64 & 2264 \\
\hline & $\begin{array}{l}\text { concoction } \\
\text { recipe }\end{array}$ & 2 & 80 & 2 & 120 & 3 & 195 & 7 & 395 \\
\hline \multirow[t]{3}{*}{ Thursday } & non- & & & & & & & & \\
\hline & $\begin{array}{l}\text { concocted } \\
\text { recipe }\end{array}$ & 20 & 520 & 23 & 897 & 21 & 966 & 64 & 2383 \\
\hline & $\begin{array}{l}\text { concoction } \\
\text { recipe }\end{array}$ & 2 & 112 & 3 & 180 & 4 & 280 & 9 & 572 \\
\hline \multirow[t]{3}{*}{ Friday } & non- & & & & & & & & \\
\hline & $\begin{array}{l}\text { concocted } \\
\text { recipe }\end{array}$ & 20 & 610 & 22 & 660 & 22 & 792 & 64 & 2062 \\
\hline & $\begin{array}{l}\text { concoction } \\
\text { recipe }\end{array}$ & 2 & 112 & 2 & 124 & 3 & 180 & 7 & 416 \\
\hline \multicolumn{2}{|c|}{$\begin{array}{l}\text { The number of non-concocted } \\
\text { Prescription per session }\end{array}$} & 100 & 2910 & 108 & 3720 & 112 & 4771 & 320 & 11401 \\
\hline \multicolumn{2}{|c|}{$\begin{array}{l}\text { The number of concocted } \\
\text { Prescription per session }\end{array}$} & 9 & 465 & 11 & 685 & 17 & 1117 & 37 & 2267 \\
\hline \multicolumn{2}{|c|}{$\begin{array}{l}\text { Average non-concoction } \\
\text { recipe per session }\end{array}$} & & 29.10 & & 34.44 & & 42.59 & & 35.62 \\
\hline \multicolumn{2}{|c|}{$\begin{array}{l}\text { Average concoction recipe per } \\
\text { session }\end{array}$} & & 51.67 & & 62.27 & & 65.70 & & 61.27 \\
\hline
\end{tabular}

The following is a display of waiting time data in the form of a bar graph which can be seen in Figure 1.

The waiting time observation process starts from receiving the prescription, prescription fuses, drug data input, printing labels, taking / packing/compounding until delivery. One of the main factors influencing the length of waiting time for prescription services at USU's pharmaceutical installation, there are three phases, the first of which is the time of receiving the prescription. Admission is carried out by the pharmacist who is concurrently doing the screening. At the time of screening, there were several problems, for example, the incompatibility of the prescription with the patient's medical history so that the pharmacist confirmed it to the clinic or doctor concerned, the computer system/program was limited, at one time there was damage or refilling of the patient's queue number printing paper so that the work for prescription screening became are hampered and there are several Prescription that are done without queue numbers, such as prescriptions for general patients and ER.

The second phase is when working on the recipe for the concoction, in caseit takes a long time to work on a concoction recipe, starting from crush the drug to wrap the mixture. The third phase is 
moment submission, when submission is done, the patient is called through the queue number system. Sometimes, when the medicine has finished working then it is put onThe medicine basket is then handed over to the patient by calling accordinglyserial number. But at one point in time the finished drug piled up onthe drug delivery table, this is due to waiting for processing the prescription withthe first queue number to be submitted. Also, the availability of drug vacancies can also delay the waiting time for prescription services because additional time is needed to confirm doctors or provide empty medicines. As conveyed by the informant as follows:

The delay in prescription is one more factor because there is a drug void, so you have to find the medicine first or confirm to the doctor for the substitution of the drug, that will take time to wait, sometimes the prescription is incomplete and you have to confirm the wrong doctor prescribes it" (Informant 2).

Some factors that contribute to the long waiting time for prescription services include the type of prescription, the number and completeness of prescriptions, the availability of sufficient and skilled human resources, the availability of appropriate drugs, and adequate facilities and facilities [9]. The number of prescriptions received at the outpatient pharmacy installation is also a factor that affects the waiting time for prescription services. Also, the number of drug items per prescription, and the number of concoctions in each prescription affect the length of waiting time for prescription services [10].

Workload affects patient waiting time, one of which is the lack of staff or doctors [8]. Doctors often practice late and lack of supervision from the management results in the accumulation of patients. The same thing was stated by [10], namely, the recipe comes together to increase the waiting time for the queue. Doctor service system intervention needs to be considered, namely early examination of patient services. Prescriptions received above 11.00 WIB have a longer waiting time than Prescription received at 09.00-11.00 WIB, because starting at $11.00 \mathrm{WIB}$ all poles are complete in providing their services so that in pharmaceutical installations there is also a buildup of prescriptions [10].

Human resources (HR) in terms of quantity are still inadequate, the number or at least of pharmaceutical technical personnel in the hospital pharmacy greatly affects the speed of prescription services at the installation.the. Officers consisting of 4 pharmacists who carry out their respective duties include 3 pharmacists and 1 pharmacist in charge of handing over drugsto outpatients as well as 5 pharmaceutical technical personnel on dutyin working on non-concocted or concocted Prescription. Based on Permenkesnumber 56 of 2014 concerning Hospital Classification and Licensing, HRGeneral Hospital class $\mathrm{C}$ for pharmaceutical personnel on duty in nursingwalk 2 (two) pharmacists assisted by at least 4 (four) staff pharmaceutical technicality [11]. Meanwhile in Permenkes No. 72 years2016 regarding Standard of Pharmaceutical Services in Hospitals, explained thatcalculating the need for a pharmacist based on the workload in the 
serviceOutpatient pharmacy which includes managerial pharmacy services andclinical pharmacy services with prescription review activities, drug delivery,Recording of Drug Use (PPP) and counseling, ideally it takes manpowerPharmacist with a ratio of 1 pharmacist to 50 patients [6]. As conveyed by the informant as follows:

"The speed at which drugs are taken is sometimes hampered because there is a vacuum of drugs in the pharmacy installation, so they are taken to the pharmacy warehouse which takes a long time, plus pharmacist assistants who are slightly outpatient. Patients' certain hours increased so that we were unable to take medicine quickly "(Informant 3 ).

According to research conducted by Wijaya (2012), the length of waiting time is influenced by human resources, type of patient, type of prescription, availability of drugs, doctor's prescription, facilities and infrastructure, drug formularies, standard operating procedures (SOP) for prescription service and factors of prescription service processes.includes receipt of prescriptions, pricing of drugs, payment, taking and compounding of drugs, providing drug labels, and delivering drugs to patients. Totalthe prescription received at the pharmacy depot is also a factorthat affects the waiting time for prescription services. Moreover, the number of medicinal items perrecipe and the number of recipe concoctions also affect the length of waiting for timeprescription services [12].

\section{Conclusion}

Based on the results of research conducted at the Outpatient Pharmacy Installation at the University of Sumatera Utara Hospital, non-concocted prescription drugs meet the requirements if the service time speed is $\leq 30$ minutes and the concocted drug prescription fulfills the requirements if the service time speed is $\leq 60$ minutes.

\section{REFERENCES}

[1] Ministry of Health of Indonesia, Minimum Hospital Service Standards No. 129/MENKES/SK/II/2008. Decree of The Minister of Health of Indonesia, p. 13. 2018.

[2] Law Of The Republic Indonesian, Republic of Indonesia Law No. 36 on Health. Jakarta. 2009.

[3] Ministry Of Health Of Indonesia, Regulation Of The Minister Of Health Of Indonesia No. 72 about Standard of Pharmaceutical Care in Hospital. Jakarta. 2016.

[4] F. Nurjanah, F. R. R. Maramis, and S. Engkeng,Relationship Between Times Wait for Prescription Services with Patient Satisfaction at the Pharmacy Complement to Kimia Farma, Prof. BLU. Dr. R. D. Kandau Manado. 2016

[5] S. Lemeshow, D. W. Hosmer. J. Klar, and S. K. Lwanga, "Adequacy of Sample Size in Health Studies," Published on behalf of the World Health Organization, England. 1990.

[6] Ministry Of Health Of Indonesia. Good Pharmacy Practice (GPP), Jakarta. 2012.

[7] H. Karuniawati, I. G. Hapsari, M. Arum, A. T. Aurora, and N. A. Wahyono,"Evaluation of the Implementation of Minimum Pharmacy Service Standards in the Category of Long Waiting Time for Outpatient Prescription Services at the Salatiga City Hospital. Kartika Journal of Pharmaceutical Science, vol. 4, no. 1, pp. 20-25. 2016. 
[8] R. Septini,“Analysis of Waiting Time for Patient Prescription Services for Outpatient Health Insurance at the Pharmacy Yanmasum RSPAD Gatot Subroto Period 2011," Tesis, pp. 7-35. 2012.

[9] H. Wijaya, "Analysis of Implementation of Minimum Service Standards for Hospitals in the Pharmacy Sector at the Pharmacy Installation at Tugu Ibu HospitalPeriod 2012," Tesis, pp. 55. 2012.

[10] A. Maftuhah and R. Susilo,"Waiting Time Services Outpatient Prescription in Depot Pharmacy RSUD Gunung Jati Cirebon in 2016." Journal of Pharmacy, pp. 39-44. 2016

[11] A. Mashuda, Guidelines for Good Pharmacy Practice. Jakarta: Ministry Of Health Of Indonesia. 2011.

[12] A. Puspitasari, "Analysis of Waiting Time for General Patient Prescription Services in Outpatient Pharmacy Depot at Karya Bhakti Work in 2011," Tesis, Universitas Indonesia, Depok, pp. 62. 2011. 